\title{
THE RESIDUE OF MILITARY REGIME DURING THE EARLY DEMOCRATIZATION ERA IN INDONESIA AND MYANMAR
}

\author{
Insan Praditya Anugrah \\ Political Science Lecturer at Open University of Indonesia, \\ Researcher at CIC Research Institution and Social Consultant \\ Email: insanradit@gmail.com
}

\begin{abstract}
This paper is a comparison of democracy structure between two Southeast Asian Nations, Indonesia and Myanmar during their early periods of Post-Praetorianism era where the state was controlled and dominated by the military. This paper found that In Indonesia, democratization after reformasi era in 1998 had successfully changed the structure of power, where the military determination in politics had been decline significantly, despite the military still hold the power to influence political and economic affairs. In Myanmar, the democratization was a result of long term transition previously planned by the military regime, so even in 2010 democratic election, the military still hold the control over the politics and tend to preserve their power within the new face of democratic system.
\end{abstract}

Keyword: Democratization, Military Regime, Southeast Asia

\section{INTRODUCTION}

Both Indonesia and Myanmar were under the rule of military authoritarian government for decades. In Indonesia, the New Order regime was overthrew in 1998 after the series of students protests across the country, following the economic decline caused by Asian Financial Crisis in 1997. President General Soeharto was forced to step down, as Indonesia entering reformation era toward more democratic political system. Unlike Indonesia, Myanmar politics were not effected by Asian Financial crisis. The totalitarian government of military Junta were more repressive against any kind of protests, so the totalitarian regime could endure until 2010, where they planned to adjust themselves with democracy. The consequence is, the new constitution draft was made to appear the democratic face of new era but in fact, still accommodate the military interests. The political changes in Myanmar seems to be insignificant since the elected President, Thein Sein was the High-rank General in the Myanmar military. both Indonesia and Myanmar military regime were experiencing ruler praetorian government, as the regime ruled for more than two decades and had the active military and former military member, as well as military as an institution participated in political affairs.

The structural change in Indonesia happened after the mass protests overthrew of the regime and reformation had made the active military function in politics officially ended. Through the abolition of Military dual function in 2000 and the abolition of military faction in the parliament, the military has lost its function as a "stabilizer and dynamist" of government. In Indonesia, the mass protests overthrew Soeharto's New Order regime, but Myanmar did not overthrow the military junta regime, the new constitution in 2008 was carried out by the military regime. Therefore, the 2008 constitution still accommodates military interests. This was proven when the initial transition to democracy through the 2010 general election, the military still had the power to carry out its will to rule, the election when it was followed and dominated by military forces that created a political party called the Union Solidarity and Development Party (USDP). The military is still strong in the Myanmar government structure towards democracy. 


\section{RESEARCH METHODS}

This paper are using descriptive-qualitative methodology, with literature reviews and historical trajectory as the instrument in collecting data and facts. Through the literature reviews and historical trajectories, this paper is examining hypothesis of how Indonesia's democratization process was more successful than Myanmar, as the military regime in Myanmar were more in the control of political affairs compared to the military Indonesia

\section{THEORETICAL APPROACH}

To examine how the remaining of military groups power affect the political affairs in early democratization era, this paper will use Erick Nordlinger's praetorianism theory, to see where the remaining military groups stands in both countries, The term praetorian army itself comes from ancient Roman times, where the emperor formed a special military unit called the praetorian soldier. This praetorian warrior ate himself, that was, overthrowing the emperor and controlling the process of succeeding the succession of the next emperors or rulers. The praetorian warrior in fact possessed a strength that was not inferior to the emperor who formed the praetorian.

Praetorianism can also be seen as military intervention in politics that occurs in the events of military coups by the government which cause the military to take control of state power. Nordlinger describes pretorianism as a situation where members of the military are the main political actors because they use real force or threats they have. Military pretorianism occurs when the government regime that was previously a civilian regime is replaced by a military government regime, although there are still some civilian actors who have considerable political influence over the government.

Generally, there are three tupes of military praetorianism accrdinf to Erc Norlinger. The forst type is Moderator Praetorian, is the condition where the military has veto power over government and political decisions without having to control the government. Under certain conditions they will coup a government they do not like and replace it with another civilian government they like. Pretorian moderators try to maintain the status quo, both stability and instability caused by competing civilian groups, The Second type is The Guardian Praetorian is a military group that carried out a coup against a civilian government whose legitimacy was experiencing a crisis, but military rule did not last for long, only 2-4 years, then they will return the power to the civilian government after political conditions under control. As long as the military is in power, the government will be authoritarian, political rights, freedom and civil competition are limited or maybe even eliminated, until the army returns to the barracks and returns the government to civilians. The third type is ruler praetorian, is the condition where the military have high political and economic ideals and sometimes they consider themselves to be radical and revolutionary modernizers. The praetorian ruler not only became the ruler of government, but also dominated the regime and controlled most of political, economic and social life through the formation of mobilized structures. Having certain political and economic ideals, this military regime lasted much more than a guard military which only ruled for two to four years. The ruling military can be in power for 20 to 30 years.

\section{INDONESIA AND MYANMAR DURING MILITARY RULE}

In Indonesia, The New Order regime never declare themselves as militaty junta or military government, however the military was dominate and determine every political process since the decline of President Soearno's power in 1966. But in facr, The New Order regime put military officers in every important position in government, most of them were from the Army, the place where the New President, General Soeharto came from. Military is the main actor in creating the "New Order" era led by General Soeharto, along with other actorsm the technocrats and the bourgeoisie. Together, those three were the foundation of the 32 years military-dominated New Order regime (Hadi, 2005: 59). The Military Dual Function (Dwifungsi ABRI) concept, to realize the idea that the military act as the guardian of the nation to maintain the social-political dynamics and stability of the country. Those social-political dynamics and stability of the country are needed to accelerate ecomonic development, after the chaotic economic condition 
during President Soekarno era. According to Nordlinger, the position of the military under New Order can be categorized as ruler praetorian, as they determined everythings related to political and social affairs, even formally, the New Order government was not a military junta.

Basically, the New Order form of government was a continuation of Soekarno's guided democracy style which was presidential without a prime minister who gave the president more room to govern the country. The Armed Forces of the Republic of Indonesia (ABRI) were indeed the main pillars of the founding of the New Order regime, however ABRI was not institutionally linked or formally regulated to produce input from a decision-making process. The New Order regime was more focused on the figure of General Soeharto, who was a President with a military background who then selected confidants, bureaucrats, and cabinet members from the power structure of the military.

After 1966, Major General Suharto (later General) began to control the government and had the right to appoint 100 members of parliament, most of whom were appointed military. After the 1971 general election, Suharto simplified political parties to a far less number than Soekarno did. Political parties in Indonesia are simplified into two political parties, the United Development Party (PPP) and the Indonesian Democratic Party (PDI). The Soeharto government then integrated functional groups into a block under military control, known as Golongan Karya (Said, $2002: 85$ ).

Despite not a Political Party, Golongan Karya was participated in every elections and could sit in parliament and is known as a government faction. Golongan Karya was supported by the military and government civilian bureaucrats. In every election, Golongan Karya always gets a majority vote. The strength of the Golongan Karya plus the ABRI (military) faction in the parliament has made Soeharto's government strong in the absence of a challenge from the Parliament. With a majority vote from the military and Golkar in the Parliament, the power of the New Order remained absolute because the military vote whose people Suharto appointed to combine with Golongan Karya had made the votes of the other two parties each share only about $15 \%$ of the total (Sundhaussen,1995: 771).

The role of the military was so strong in political affairs and business until early 1990s. In the early 1990s, Suharto began to feel threatened by the military when it was already talking about leadership succession, while he also had personal ambitions to defend his family and his closest aids in the political and social structure. The military as a political force began to be sidelined since Soeharto had Islam as a new coalition, However, Soeharto regime was ended triggered by Asian financial crisis in 1997 and later mass student protests over Soeharto's corrupt government. In May 211998 the mass protests successfully forced Soeharto to resign from his post, and Indonesia officially entering Democratic Reformation era and the end of military dominated "New Order" regime.

In Myanmar, since 1948 the previous government was in civilian hands before in 1962 General Ne Win staged a coup and seized power in Myanmar from Prime Minister U Nu. In the era of civilian government, Myanmar was a country with a parliamentary system where the power of the head of government was in the hands of the prime minister while the head of state was the President. The power of the former prime minister $\mathrm{U}$ Nu was very dominant as Prime Minister. Because it is a parliamentary system government, the position of the President is only as the Head of State and does not have a major role in making government policies.

During the civil era where $\mathrm{U} \mathrm{Nu}$ was dominant as the Prime Minister, there were 3 Presidents who had served in Burma, including Sao Shwe Thaik, Ba U and Win Maung. After the military coup in 1962, Myanmar was ruled by a Revolutionary Council led by a general named Ne Win. The junta's authoritarian government wanted a centralistic government in the style of the Soviet Union. After the new constitution in 1974, the party system in Myanmar changed from previously consisting of several parties into a single party system.

Since the military rule during both the socialist era led by Ne Win and the SLORC regime in the late 1980s, Myanmar is a country with the form of a military junta, in which power is in the hands of a military group led by a Council of Generals, then the generals who become the leaders are Senior Generals. . This system was different from the New Order and the Dual Function concept where Suharto had seen a more central role in determining which military officers would be around him to maintain his own power. Since Myanmar was a Military Junta, it was 
Insan Praditya Anugrah-The Residue of Military Regime...

obvious that the praetorianism in Myanmar was a ruler praetorianism, according to Nordlinger's theory.

\begin{tabular}{|c|c|c|c|}
\hline No. & Indicator & Indonesia & Myanmar \\
\hline 1 & $\begin{array}{c}\text { Form of } \\
\text { Government }\end{array}$ & $\begin{array}{l}\text { Military Dominated } \\
\text { Government }\end{array}$ & Absolute Military Rule \\
\hline 2 & $\begin{array}{c}\text { Military } \\
\text { Involvement In } \\
\text { Politics }\end{array}$ & $\begin{array}{c}\text { Dual Function System } \\
\text { of The Military }\end{array}$ & Military Council/ Junta \\
\hline 3 & $\begin{array}{l}\text { General } \\
\text { Election }\end{array}$ & Every Five Years & $\begin{array}{l}\text { Rarely Held General } \\
\text { Election }\end{array}$ \\
\hline
\end{tabular}

Source: From Multiple Sourves

\section{INDONESIA AND MYANMAR DURING THE EARLY STAGE OF DEMOCRATIZATION}

In Indonesia the authoritarian New Order regime was successfully overthrown by students and activists in 1998. The military, which previously had a dominant role in politics and business formally until Suharto's fall, is still in strategic positions of power made possible by ABRI's dual function. The military / ABRI still have a position in parliament to support them, but since the 1990s, Suharto actually started to minimize the role of military generals because he had started discussing the issue of leadership succession.

From 1990 until its fall in 1998, the New Order led by President General Soeharto began to move away from and minimize the role of the military. Soeharto had started to think about himself, his cronies and children, and found Ikatan Cendikiawan Muslim Indonesia (ICMI) and Muslims as new allies. This affected the reform era, the implementation of government and the implementation of the 1999 elections, which were followed by many political parties without military interference. Military involvement in national politics has ended since the abolition of ABRI's dual function through TAP MPR RI NO. VI / MPR / 2000. Since the fall of Soeharto until the first democratic elections in 2004 there was a transitional era filled with the reign of President B.J. Habibie, who rose from the position of vice president to rule 1998-1999, President Abdurrahman Wahid in 1999-2001, and then President Megawati Soekarnoputri in 2001-2004.

Habibie became President because he replaced Suharto from the position of Vice President, Abdurrahman Wahid became President because of a coalition of Islamic parties in parliament after previously obtaining votes in the 1999 general election for political parties while Megawati Soekarnoputri rose to President after replacing Abdurrahman Wahid from her previous position as Vice President. General elections democratically electing members of the new legislature were held in 2004. As General Soehartp's successor, President Habibie provided a smoth transition to civilian supremacy. He provided flexibility for the military to formulate its own reform agenda. The smooth transition is a realistic decision, as rhe president needs military support to stabilize power amid the weak legitimacy of his leadership, as General Soeharto's successor. On the other hand, the military needs the full support of the president so that internal military interests are maintained (Mietzner, 2006: 11). On October 5, 1998, the Military New Paradigm was introduced which defines the separation of Police from the military;. It was also followed by The reduction of the number of military representatives in the legislative body, and a promise to maintain the neutrality of the military related to the political affairs. One year later, the military's New Paradigm began to be implemented through the separation of the police from military in April 1999, due to the military faction's seats from 75 to 38, termination of ties with Golkar, and the abolition of military dual function concept. Thus, there has been a fundamental institutional change within the Indonesian military in relation to civil-military relations. 
The 2004 Election was a historic year because for the first time the general election involved all the people of Indonesia in the form of direct elections for President and Vice President by the people. On April 5, 2004, Indonesia successfully held the first phase of the general election, it was legislative election which was attended by around 24 political parties. This general election was won by the Golongan Karya Party with $21.8 \%$ followed by the second and third rankings respectively the Partai Demokrasi Indonesia-Perjuangan (PDI-P) with $18.53 \%$ and the Partai Kebangkitan Bangsa (PKB) with 10.57\% while 21 other political parties received less than $10 \%$ of the votes. Furthermore, the general election for the President was held in two rounds, on 5 July 2004 for the first round and 20 September 2004 for the second round (Vaughn, 2005:1).

In the second round, the choice between Susilo Bambang Yudhoyono-Jusuf Kalla and the pair Megawati Soekarnoputri-Hasyim Muzadi. This election was won by Susilo Bambang Yudhoyono-Jusuf Kalla in the second round. In the first round the most votes were obtained by the pair Susilo Bambang Yudhoyono-Jusuf Kalla with 33.6\%, Megawati-Hasjim Muzadi with 26.6\%, Wiranto-Solahuddin Wahid 22.2\%, Amien Rais-Siswono Yudho Husodo $14.7 \%$ and Hamzah. Haz-Agum Gumelar 3.0\%. The second round was won by the pair Susilo Bambang Yudhoyono-Jusuf Kalla with 60.7\%, Megawati-Hasjim Muzadi with 39.4\% (The Carter Center, 2004: 63).

On the surface, the military might disappear from political affairs, however at least until Abdurrahman Wahid precidency, the military still hold important power to influence the political spheres. Wahid era was the transition toward civilian supremacy, despite the military, according to Erick Nordlinger's definition of praetorianism, was still in a form of praetorian but just transformed from ruler praetorian to moderator praetorian, or even weaker because the military in Wahid Presidency was no longer a predominant actor in politics but still have enough power to influence political result. In parliament-Wahid crisis, the military took the momentum to support parliament to overthrow Wahid from his Presidential post (Malik, 2003: 308-321). If we relate thiese phenomenon with Nordlinger's praetorianism classificasion, the Miitary under Wahid administration can be classified as less powerful than moderator praetorian type, because their power were no longer sufficient to take down a civilian government themselves, so they should find another political actors such as parliament to overthrow the government.

The reform era was indeed followed by abolition of social, political and economic functions (dual function) of the military. However, the military group was still have a significance and power to influence political affairs- proved by the involvement of retired generals that participated in the Indonesian politics. Former military generals such as Prabowo, Wiranto, Luhut Binsar Panjaitan, Gatot Nurmantyo, Agum Gumelar and Moeldoko became influential politicians in the reform era. The most remarkable retired military general was Susilo Bambang Yudhoyono managed to rule as President for 10 years.

Despite the influence of the military was far less than the New Order era (Naim, 2017). According to Nairn, many former generals or even active military officers in Indonesia still have human rights violation issues such as the murder of Human Rights activist Munir, the 1965 massacres and 1998 violence and human rights violation in East Timor and Papua. Apart from the issue of human rights, there was also an issue related to business concession. Looking at its history, the military had been involved in managing state business since the nationalization of foreign companies in 1958 and then in 1965 the role of the military in business increased by controlling various concessions and license grants to entrepreneurs. Until Joko Widodo era, there are still a numbers of high-ranking military officers in Papua who establish patron-client relationships with foreign enterprises in Papua. These military personnel clearly have an interest in all Freeport business activities in Papua (Supriyono, 2016). The social, political and economic roles of the military has been formally revoked by the elimination of dual function, but the military power behind the scenes in the current era is a matter of concern because it can threaten Indonesia's democratic future

Unlike Indonesia, In Myanmar the democratization process was not happened because the stufents overthrown previous authoritarian regime, but the transformation arranged by the military Junta regime itself. The transition period to democracy itself began in 2011 when the junta government structure began to be slowly transformed into a civilian-style government. In the 2010 general election, the government party The military junta Union Solidarity and 
Development Party (USDP) won back the general election with a majority vote that reached more than $90 \%$, this election did not reflect the will of the real majority and many were boycotted by other political parties in Myanmar . The president-elect of Myanmar from the 2010 general election is still a military general Thein Sein (BBC News,2017).

The year 2011-2015 was the Myanmar's transition and political reform periods, with the release of pro-democracy activist Aung San Suu Kyi and other pro-semocracy people. The government also held subsequent dialogues with Suu Kyi as the political opposition leader. Myamar also establish National Human Rights Commission, and grant amnesties for hundreds of political prisoners, institution of new labour laws that allow labour unions and strikes, relaxation of press censorship, and regulations of currency practices. The transition to democracy has actually been formulated in the 2008 constitution. It was only in 2015 that Myanmar held general elections which became a bridge for Myanmar's democratization, although it was still not free from military privileges. This general election was attended by all political parties including those who previously carried out boycotts (Carter Center, 2015: 5-6).

In 2015, the post- military regime of Myanmar held general election. The election were the first openly contested since 1990, which was annulled by the military government after the National League for Democracy's (NLD) victory. The general election resulted a victory of the National League for Democracy (NLD) party which controlled 79\% of the vote, which means winning a majority of votes in 10 of the 14 regions and regional assemblies. The second rank is the military party, namely the Union Solidarity and Development Party (USDP) which controls a total of $8 \%$ of the vote, while the rest are other parties (Carter Center, 2015: 61-62)..

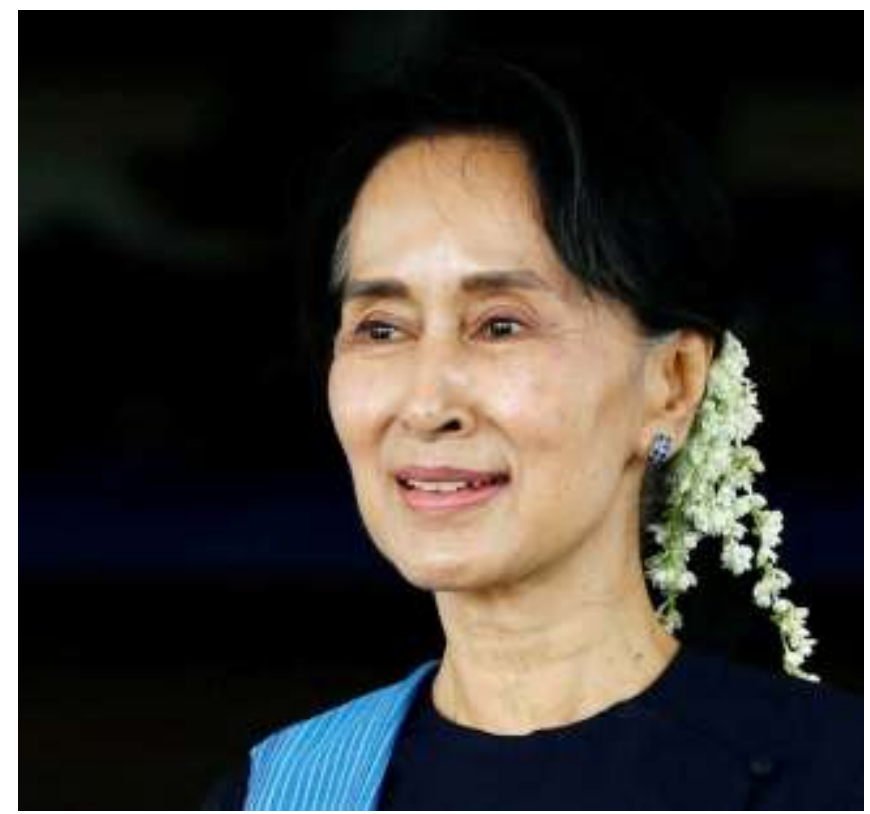

Picture 1: Myanmar Opposition Leader, Aung San Suu Kyi Source: Independent.co.uk

This victory made Aung San Suu Kyi, who was nominated by the NLD, to defeat the previous President, General Thein Sein and should have run as President. However, the new constitution in 2008 which was prepared by the military actually prevented people with children / husbands of foreign nationalities from becoming President. This is most likely the military's anticipation to prevent the democratic process from running quickly with Suu Kyi as President. Because of this regulation, the new government was forced to create a State Counselor position that would function as head of government for Aung San Suu Kyi. The post of State Counsellor is similar to that of a Prime Minister in that it allows the holder to work across all areas of government. The State Counsellor has a term of five years, the same term as that of the President. The state counselor role is widely seen as an attempt to protect Suu Kyi from accusations that she is acting unconstitutionally by taking on so much power. In both houses, the military-appointed bloc, 
which holds 25 percent of seats were strongly objected to the measure, saying it bypassed the military-drafted constitution. Suu Kyi passed the lower house, despite all military-appointed lawmakers abstaining from the vote after House Speaker Win Myint refused to permit more time for its review (Lynn, 2016).

Although this general election is an important step towards transition democracy, the role of the military is still significant, in contrast to the New Order regime in Indonesia, whose role of militias has diminished considerably since the early 1990s. The Myanmar military still has the privilege of electing $25 \%$ of parliamentarians at both the national and regional levels. The military also still has the privilege of choosing the minister of defense, interior minister and minister of border affairs (Carter Center, 2015: 6).. During the democratic process, the Myanmar military still participates in political affairs by forming parties to maintain the possibility of military group could intervene the politics through the Party that could compete in the election. The Party called Union Solidarity and Development Party (USDP).

\section{CONCLUSION}

Indonesia and Myanmar shared similar experience under the military rule, so it is interesting to examine how both countries carried out the first democratic elections after the transition era from authoritarian regimes, that previously dominated by the military. Using Eric Nordlinger's categorization of praetorianism, both Indonesia and Myanmar military regime were experiencing ruler praetorian government, as the regime ruled for more than two decades and had the active military and former military member, as well as military as an institution participated in political affairs.

The New Order was actually formally a civilian government and not a military junta, it's just that this regime did indeed stand on the pillars of the military and technocrats, because the new order was born from the rise of the Army in the Indonesian political structure, the New Order regime was also more dominated by the figure of General Soeharto than military institutionally. In essence, the military in this regime is only a pillar of regime power. This is different from Myanmar where the military junta since the era of the Socialist Junta General Ne Win to the era of the SLORC Junta General Than Shwe was a military government.

In the junta, the military hierarchy structure also means government because the government is led by a military council. Gabriel Almond and Gabriel Almond's structuralfunctional approach compares structure and function as well as observes the creation of structures and functions generated by the dynamics of political history in previous eras. The variables being compared include the position of the military function and the forces of the old regime and their influence in the new structure, the function of the new pro-democracy power in the new structure and how the two forces are involved in determining the composition of the government and parliament.

In the case of Indonesia, the change in structure occurred because the overthrow of the regime and reformation had made the active military function in politics officially ended. Through the abolition of ABRI's dual function in 2000 and the abolition of the ABRI (military) faction from the parliament, the military has lost its function as a "stabilizer and dynamist" of government. The supporters of democracy also rose in the government and parliament such as Amien Rais, Abdurrahman Wahid and Megawati Soekarnoputri even before the 2004 general elections. Golongan Karya (Golkar) as a non-political party New Order political machine since the reform era transformed itself into the "Golkar Party".

However, the retired military officer still able to influence political affairs and became predominant actors in democratic system. Retired Generals such as Agum Gumelar,Luhiut Binsar,Gatot Nurmantyo,Wiranto,Moeldoko still able to gain public support or party support to include them within new government structure. General Prabowo even able to participated in general election for 15 years and General Susilo Bambang Yudhoyono ruled Indonesia for 10 years, the maximum term in democratic system. Human rights issues that involving the retired generals also remains untouchable and numbers of active high ranked military officers still able to have a patron-client relationship for the foreign enterprises in Papua.

Unlike Indonesia, which overthrew Soeharto's New Order regime, Myanmar did not overthrow the military junta regime, the new constitution in 2008 was carried out by the military regime. Therefore, the 2008 constitution still accommodates military interests. This was 
proven when the initial transition to democracy through the 2010 general election, the military still had the power to carry out its will to rule, the election when it was followed and dominated by military forces that created a political party called the Union Solidarity and Development Party (USDP). The military is still strong in the Myanmar government structure towards democracy. Related to Nordlinger's categorization, we can say that in democratic era of Indonesia, the military power to influence still exist but even weaker than the moderator pmraetorianism type that Nordlinger stated. In Myanmar, the transition was prepared by the military government and theor involvement in political affairs, such as some privileges and the existence of military party to compete in democratic era make the military position is inbetween. It was stronger than the moderator praetorian and weaker than the ruler praetorian

This was also the reason the parties boycotted the election results. In the 2015 general election, the military still has the right to elect $25 \%$ of parliamentarians at the national and regional levels, as well as the privilege of determining the minister of interior, minister of defense and minister of border affairs. Meanwhile, the supporters of democracy in the government of the National League for Democracy (NLD) also still have to negotiate with military forces in the government and in the parliament. The constitution made by the military contains provisions that the President may not have a husband / child with foreign nationality, which does not allow Aung San Suu Kyi to become President. It is also an example of the influence and function of the military group that is still large in determining the structure of Myanmar's government even after the transition era.

\section{REFERENCES}

Alan Nairn, A. (2017). Investigation Journalist. Interviewed by Aiman WIcaksono from Kompas TV https://www.youtube.com/watch?v=U9Q5nkXx28c

BBC News (2017). Myanmar Profile-Media. Retrieved, October 8, 2019 from http://www.bbc.com/news/world-asia-pacific-12991727

Carter Center (ed). 2015. Observing Myanmar's 2015 General Election-Final Report. Carter Center

2005. The Carter Center 2004 Indonesian Election Report. Carter Center

Crouch, H. (2007). The Army and Politics In Indonesia. Singapore : Equinox Publishing (Asia) Pte Ltd

Lynn, , K, Y. (2016). Myanmar MPs approve Suu Kyi as 'advisor to state'. Retreived, November 13, 2020 from https://www.aa.com.tr/en/politics/myanmar-mpsapprove-suu-kyi-as-advisor-to-state-/549634

Mietzner, M. (2006). The Politics of Military Reform in Post-Suharto Indonesia : Elite Conflict, Nationalism, and Institutional Resistance. Washington: East West Center, Said, S. (2002). Tumbuhnya dan Tumbangnya Dwifungsi ABRI. Jakarta: Aksara Karunia, Sundhaussen, U. (1995). Indonesia's New Order : A Model For Myanmar?. Asian Survey Vol. 35 No. 8. University of California Press

Supriyono, J. (2016). Anthropologist specialized in Papua issues. Interviewed on May 11 2016

Transnational Institutr (ed). 2015. The 2015 General Election In Myanmar : What Now for Ethnic Politics?. Transnational Institute. Myanmar Policy Briefing Vol. 17

Vaughn, B. (2005). Indonesian Election. Congress Research Service-The Library of Congress May 20

Copyright (C) 2019, JCIC - Journal of CIC, Social Consultant and Research Institute 79 